\title{
Jak pisał swój pamiętnik kanonik gnieźnieński Baltazar Pstrokoński
}

Konwencje literackie starzeją się $i$ więdną. Wyznania człowieka z krwi i kości - nigdy ${ }^{1}$

\section{Wstep}

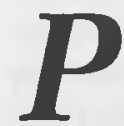

amiętniki XVTII w. stanowia wczesny etap rozwojowy naszego pamiętnikarstwa. Stąd cały szereg pytań, które zwykle badacze stawiają materiałowi pamiętnikarskiemu, nie moze być tutaj adresowanych. Chodzi tu przede wszystkim o sprawy związane $z$ osobowościa pamiętnikarzy, problematylką szczerości, świadomych przemilczeń. Nie można w tym materiale wynajdywać świadectw społecznego nieprzystosowania bohaterów, ani poszukiwać napieć, o których Ernst T. Krueger przekonująco twierdzi, ze są one motywem spisywania pamiętników-wyznań - napisał w swojej pracy o pamiętnikach XVIII w., znany badacz twórczości autobiograficznej Andrzej Cieński².

W świetle rozwoju badań nad materiałami autobiograficznymi, podejmowanymi w zakresie różnych dziedzin wiedzy, m. in. socjologii, psychologii, językoznawstwa, wydaje się - wbrew przytoczonej wyżej opinii - że również pamiętniki wcześniejsze, nie tylko współczesne mogą być rozpatrywane nie jedynie w sensie analizy szczerości wypowiedzi ich autorów, czy weryfikacji przedstawianych przez nich danych faktograficznych. Mogą być one téz analizowane poprzez pryzmat kształtujących je społecznych mechanizmów, czynników i warunków wiążących się ze zdolnością przeżywania i opowiadania o swoin życiu, jako o "historii” oraz o kształtujących sposobach i technikach zarówno życia, jak i interpretacji ${ }^{3}$.

Warto chyba podkreślić fakt, że podstawą analizy materiałów pamiętnikarskich, niezależnie od tego, z jakiego pochodzą okresu historycznego oraz jaki przekrój społeczny przedstawiają, jest określenie, jaki - w znaczeniu Saussure'owskim - reprezentują typ mowy (parole), nie języka (langue). Kusząca jest bowiem perspektywa analizowania pamiętników XVIII-wiecznych pod względem języlka pojmowanego jako technika życia, jako zasób wiedzy zawartej w jego kategoriach i pole możliwości otwierane przez jego semantyczne odniesienie. Bowiem - jak pisze Anna Giza - „Interpretowanie i opowiadanie, a nawet doświadczanie dokonuje się $w$ intersubiektywnym medium języka. Wyrażona w autobiografii samowiedza nie jest więc prostym sprawozdaniem $z$ tego co się komuś „rzeczywiście” przydarzyło. Język, w którym 'świat jest nam dany', współkształtuje nie tylko opowiadanie, ale również postrzeganie zdarzeń. Da- 
starcza on znaczeń, dzięlki którym zdarzenia mogą zostać ujęte, powiązane, wyselekcjonowane czy w ogóle wywołane $z$ pamięci"

W Pamiętnikach kanonika gnieźnieńskiego Baltazara Pstrokońskiego równiez interesujący wydaje się być ich język, którym opowiada on dzieje swojego zycia. Tekst ten można analizować, biorąc pod uwagę teorię kodów Basila Bernsteina, która przyjmuje istnienie tzw. kodu ograniczonego i kodu rozwiniętego. W największym skrócie teorię tę można scharakteryzować w ten sposób, że kod ograniczony związany jest $z$ taką wypowiedzią, która - choćby była najbarclziej złożona - pozwala przekazującemu i odbierajacemu, precyzyjnie i bez trudu przewidziec kolejne słowa i sens przekazu. Kod rozbudowany natomiast pozwala na przekazywanie indywidualnych doświadczeń jednostki. Nie traktuje on - w przeciwieństwie do kodu ograniczonego - warunków, w jakich znajduje się odbierający jako oczywistych, przekazujący musi dostosowywać swą mowę do nich oraz do specyficznych właściwości odbierającego ${ }^{5}$. Kody ograniczone w naturalny sposób są kształtowane w określonych środowiskach, posługiwanie się nimi stymuluje oczywiście określony system edukacyjny, któremu została poddana jednostka: „O ile kod ograniczony ułatwia konstruowanie i wymianę symboli, które stały się własnością ogólną, o tyle kod rozbudowany ułatwia konstruowanie werbalne i wymianę symboli zindywidualizowanych i osobistych" 6

Jednostlkę oczywiście może - i co więcej powinna - cechować umiejętność zmiany kodów i w myśl teorii Bernsteina: „Zdolność zmiany kodów rządzi zdolnością do zmiany ról” " „ponieważ kod rozwinięty pozwala kształtować technikę mowy zależnie od sytuacji. Kod jako głęboka struktura mowy, nie jest wrażliwy na doraźne zabiegi intencjonalne" ${ }^{\text {. }}$.

Tak więc można przyjąć, że opis własnego życia, czyli jego przeżywanie na nowo na użytek autobiografii, pamiętnika, czy wspomnień to pewien rodzaj jak to określiła Anna Giza - materializacji techniki życia, odzwierciedlającej zbiorowe formy solidarności, racjonalności instrumentalnej i komunikacyjnej i przeważających typów socjalizacji'.

\section{Kilka słów o bohaterze}

Baltazar Pstrokoński urodził się 1 stycznia 1713 r. we wsi Piekary w Sieradzkiem. Pochodził z niezamożnej rodziny. Dosyć wcześnie stracił ojca, który zmarł w 1720 r. i od wtedy - razem $z$ trojgiem rodzeństwa - wychowywany byl tylko przez matkę, Konstancję $z$ Grodzyńskich ${ }^{10}$. Początkowe nauki pobieral u pijarów w Wieluniu, następnie został oddany pod opiekę dalekiego krewnego, sędziego grodzkiego w Krakowie, Józefa Michałowskiego. Z synem tegoz Michałowskiego, Antonim, najpierw uczył się w domu w Słupi, następnie wstappił na Uniwersytet Krakowski, ale wkrótce zakończył naukę, aby pełnic funkcję administratora dóbr sędziego. Jednal zajęcie to nie bardzo mu odpowiadało, ponieważ w ok. 1731 r. zdecydował się porzucić swojego pracodawce i poświęcić się stanowi duchownemu. Lata 1733-1737 spędził na systematycznym uzupelnianiu swojego wylkształcenia teologicznego i filozoficznego, m.in. w kolegium jezuitów w Kaliszu i w Seminarium Duchownym w Gnieźnie. Już w 1736 r. 
otrzymał pierwsze beneficjum, kanonię w kolegiacie w Choczu, a w 1737 r., po święceniach kapłańskich, objął plebanię w Mokrsku i został dziekanem kapituły w Choczu' ${ }^{11}$.

Jako duchowny, Pstrokoński stopniowo obejmował kolejne beneficja i urzędy, m.in. został instalowany na kanonii w kolegiacie kaliskiej (1756), mianowany kanonikiem łowickim i delegatem kurii prymasowskiej, plebanem w Koninie i Złotkowie. W 1762 r. arcybiskup gnieźnieński Władysław Łubieński, protektor Pstrokońskiego, powołał go na stanowisko kanonika kapituły metropolitalnej w Gnieźnie. W 1766 r. zasiadał jako delegat kapituły gnieźnieńskiej w Trybunale Koronnym, za co rok później tytułem rekompensaty za wydatki w Trybunale otrzymał kanonię kolegiaty św. Jerzego w Gnieźnie ${ }^{12}$.

Od wiosny 1768 r. do marca 1769 r. Pstrokoński przebywal w Rzymie jako delegat kapituły gnieźnieńskiej w jej sporze $z$ zakonem bożogrobców. Do następców swego protektora, Władysława Łubieńskiego, kolejnych prymasów Gabriela Podoskiego i Antoniego Ostrowskiego - odnosił się $z$ dużą rezerwą. Nie przyjmował proponowanych mu wszystkich godności, chociaż swoją pozycję potrafil wykorzystać w celu promowania innych, m.in. na koadiutora swej kanonii w Gnieźnie przyjął synowca prymasa, Kazimierza Łubieńskiego, a w Kaliszu - Jędrzeja Kitowicza ${ }^{13}$.

Działalność Baltazara Pstrokońskiego charakteryzuje się tym, że dużą cześć swoich dochodów przeznaczał na cele publiczne, m.in. reperował i odnawiał kościoły (w Gnieźnie, Burzeninie, Koninie, Mokrsku, Złotkowie ${ }^{14}$. Spod jego pióra wyszła dokumentacja prac prowadzonych w Gnieźnie, pt. Pamiętnik reparacji kościoła metropolitarnego gnieźnieńskiego po zgorzeniul.. R. P. 1760 do roku 1788 kontynuowany, w którym uderza niezwykła trafność opisów i analiz, nowoczesne podejście do problematyki historii architektury $\mathrm{i}$ - zgodnie $z$ oceną specjalistów - stanowi on prekursorskie opracowanie tego rodzaju zagadnień w Polsce ${ }^{15}$. W Burzeninie ufundował także szkole parafialna.

Pstrokoński lubił także parać się piórem, z tym, że jego prace pozostały głównie w rękopisie (w większości zachowane w Archiwum Archidiecezjalnym w Gnieźnie). Oprócz Pamiętnika, który poddany będzie szczegółowej analizie w dalszej części artykułu „przygotował rodzaj podręcznej encyklopedii kościelnej", pt. Mieszanina materii różych potrzebnych tak do Pisma św., do Ewangelii, do rzeczy kościelnych i duchownych, jako tez do historii, do wiadomości rozmaitych, do obyczajów i rozmów nalezących, która stanowi wypisy $z$ różnych pism kościelnych, filozoficznych oraz $z$ gazet $z$ rzadkimi komentarzami Pstrokońskiego ${ }^{16}$.

Oryginalną pracę kanonika gnieźnieńskiego stanowi napisane w $1787 \mathrm{r}$. opracowanie pt. Nauki kościelne do zachowania kapłańskiego ducha... dla seminarzystów i kapłanów na rekolekcjach przebywających zdać się mogące. Jest to zbiór konferencji i rozważań dla duchowieństwa, w którym Pstrokoński skrytykował $\mathrm{m}$. in. uleganie modzie francuskiej oraz potępiał niedbałość kleru parafialnego i materializm wyższego duchowieństwa ${ }^{17}$.

Pod koniec życia Pstrokoński ofiarował spore sumy pieniędzy na różne cele, $\mathrm{m}$. in. w $1793 \mathrm{r}$. zapisał 12000 zlotych polskich na fundusz edukacyjny, $z$ którego miało otrzymywać stypendia 5 uczących się młodzieńców $z$ biednej szlachty, w tym samym roku zarządził, aby 7000 złotych polskich przeznaczyć na remont 
dzwonnicy przykatedralnej w Gnieźnie. Zmarł 14 września 1796 r. w Gnieźnie, gdzie został téz pochowany w katedrze, w kaplicy Eubieńskich ${ }^{18}$.

\section{O czym mówią Pamiętniki kanonika gnieźnieńskiego}

Pamiętniki uchodzą za najciekawszą pracę Baltazara Pstrokońskiego. Niestety oryginał ich zaginął, natomiast $\mathrm{w}$ dużej części zostały one wydane drukiem w XIX w. przez Edwarda Raczyńskiego ${ }^{19}$. W tymże wydaniu składaja się one $z$ piętnastu rozdziałów, ułożonych według chronologii życia ich autora ${ }^{20}$. Warto dodać, ze nie wiadomo, w jaki sposób wydlawca dziewiętnastowieczny „przygotowal je do druku” - tzn. nie mamy pewności, czy - w stosunku do całości rękopisu - nie dokonał skrótów w opublikowanym tekście. Na samym końcu Pamiętników, Raczyński stwierdził tylko: „Tu koniec kładziemy niniejszemu dziełu, które autor do końca życia swego pisał. Nie sąclzimy przecież, aby ostatnie lata jego pamiętników zajmować czytelnika mogły"21. Nie jesteśmy więc pewni, czy na takiej samej zasadzie nie zostały wprowadzone jakieś skróty w publikacji.

Niemniej, opublikowane Pamiętniki są pracą interesującą, wciągającą czytelnika, pozwalającą zorientować się w problemach przeżywanych przez autora, jego rozterkach i sposobie postrzegania przez niego świata. Niosą oczywiście wiele informacji autobiograficznych, ale też clotyczących innych osób, z różnych kręgów, oraz dają obraz stosunków panujących wśród osiemnastowiecznego duchowieństwa.

Wydaje się, że interesujące będzie spojrzenie na Pamiętniki Pstrokońskiego $z$ punktu widzenia języka, którym się posługuje, jakich używa „usprawiedliwień" swojego postępowania i jaki - z drugiej strony - ma to wpływ na interpretację otaczającego go świata.

Pstrokoński był osobą duchowną i oczywiście znajduje to odzwierciedlenie w używanym przez niego języku i sposobie interpretacji rzeczywistości. Widać to już na samym początku pamiętnika, gdzie w następujących słowach przedstawia cel pisania o swoich losach: „Opatrzność Pana Boga wielbię, gdy moje życie opisuję. Odkrywając maluczkie pierwiastki stanu mego cnota pokory, a głosząc podniesienie moje na kanonika gnieźnieńskiego cnotą wdzięczności, wieczne przeznaczenie pochwalam"22.

Cytat ten wskazuje wyraźnie, że swoje wspomnienia pisał Pstrokoński nie na bieżąco, jak sugeruje Marian Aleksandrowicz ${ }^{23}$, ale dopiero po otrzymaniu godności kanonika gnieźnieńskiego, czyli po $1762 \mathrm{r}$. Tłumaczy to tym samym dosyć jednolity styl wypowiedzi, stosowany w całości Pamiętników, ponieważ zaczął je spisywać już jako dojrzały, pięćdziesięcioletni mężczyzna, obdarzony znaczącymi godnościami duchownymi, co niewątpliwie miało wpływ na sposób interpretacji przez niego rzeczywistości.

Interesujące wydaje się thumaczenie Pstrokońskiego, w jaki sposób został osobą duchowną - mianowicie a propos pobierania nauki u pijarów w Wieluniu, napisał w swoim pamiętniku, że: „Pijarowie wabili mię do zakonu swego, ale woli boskiej nie było"24. W związku z tym - jak wiemy - został oddany do sędziego krakowslkiego Józefa Michałowskiego. Nie miał u niego łatwego życia, ponie- 
waż musiał towarzyszyć synowi sędziego Antoniego, ponadto - już w Krakowie, kiedy wspólnie $z$ Antonim zaczęli naukę w Akademii Krakowskiej - „trzymałem rozchód stołu naszego studenckiego, do którego należał profesor, dwóch nas dzieciuchów, sługa, hajduk i kucharka. Piec w izdebce naszej marmurem wysłanej, najtęższe mrozy trzeba było na dzień (cóż za Kraków) szczepkami dębowemi za sześć groszy opalać. Od zimna przejęty, spadłem ze schodów, rękę lewą w ramieniu wybiłem, którą baba, $z$ chlebem pod kamienicą siadająca, uleczyła" 25

Dopiero jednalk trudne czasy nastały, kiedy Pstrokoński musiał przerwać nauki i zostać asystentem sędziego Michałowskiego: „Była to dla mnie pora twardsza nad zakonne reguły i służbę wojskową. Slepieć we dnie i nocy nad piórem, w Krakowie rejestra trzymać wydatków, a po dobrach wymierzać zboża po spichrzach i rachować i zapisywać po sadach drzewa urodzajne, i drzewka najmniejsze; a po łąkach i po zapłociach (w kraju bez drew) krzaki i wierzby rachować, inwentarze opisować, stajnie, obory, na zimę otwierać, a na wiosnę spisowaniem zamykać - było to wszystko moją profesją"26

Najgorsze jednak było, że - zdaniem Pstrokońskiego - sędzia mając liczny dwór: „zawsze po trzech i czterech przy sobie paniczów na respekcie, a dworskich po dwudziestu" - wykorzystywal ponad miarę tylko Pstrokońskiego, ponieważ: „A ten cały jego liczny dwór nic nigdy nie robił, a ja sam jak kamień młyński w ustawicznym bylem obrocie. Nadto chociaż ten Pan pełno miał usłużenia, jednakże w chorobach jego musiałem ja najpodlejsze mu czynić usługi i pościółką moją wycierać przy nim podłogi. Taka jego wola była, a to czy dlatego, aby mię miał zawsze pod ręką do pisania, czyli też dlatego, abym się na obyczajach nie zepsuł. Jedzenie bywało dla mnie cale lapczywe, tak żeby go był jaki krokodyl nie jadl i grosza tez do kieszeni mi nie dawano, jakbym pozostawał w obowiązku ślubu ubóstwa. W tej ścisłości, jakbym należał do sekty stoików, to jest jakbym uczucia nie miał: wszystko bez najmniejszego sarknienia wytrzymywałem" 27.

I w tej sytuacji, jak spokojnie i rzeczowo stwierdza Pstrokoński: „Tu się powołanie moje do stanu duchownego zaczęło okazywać" ${ }^{28}$. Oczywiście sędzia Michałowski nie chciał się początkowo zgodzić na opuszczenie go przez naszego bohatera, ale: „Nic mię to od rezolucji powziętej nie cofało, więc zatem nalegalem o odjazd"29. W związku z tym sęclzia nie miał innego wyjścia, tym bardziej, że Pstrokoński powoływał się na wolę boską, więc w końcu: „Tak zatem kazał mi połowę sukienek i szabelkę cienko w sreberko oprawną zostawić sobie i odclać do swojego skarbcu, mówiąc, że mi to dał nie dla mnie, ale clla swego honoru. Wszystko więc mu zostawiłem. Dał mi zaś na odprawę szkapsko, starego srokatego ogiera, za którego w clomu złotych 20 wziąłem, a na którego mój sługa w jednym matezalku wszystek mój majątek, id est bagaż wtroczył, a na Viales dał mi sędzia bodaj kilkanaście złotych"30.

Rozstanie $z$ sędzią Michałowskim nie było więc sympatyczne dla obydwu stron, ale wyraźnie widlać z języka Pamiętników, że Pstrokoński starał się usprawiedliwić swoją decyzję, odwołując się do racji wyższych - woli boskiej, objawiającej się powolaniem do stanu duchownego.

Dalej następuje krótki opis pobytu w seminarium gnieźnieńskim (1 września 1733 r. - 1 lipca 1734 r.), gdzie Pstrokoński dał się poznać jako przykładny kle- 
ryk, bowiem, jak stwierdza: „A lubo kapituła gnieźnieńska, prałaci i kanonicy mieli oko na mnie i chcieli mię przy katedrze utrzymać i na ten koniec już mi tytuł do kapłaństwa zapisali, że jednak mi lat trzy do niego brakowało, postanowiłem te trzy lata odłożyć na nauki, które by mię uczyniły sposobniejszym do służenia kościołowi. Jakoż w domu przez wakacje zabawiwszy, udałem się do szkół kaliskich, w których przez lat trzy kurs filozoficzny traktowałem, i na osobności, w cichości ducha, obywałem się bez rozrywek i samej tylko książki pilnowałem" ${ }^{31}$.

W całych Pamiętnikach zresztą można zauważyć, jaką estymą clarzy Pstrokoński książki, czytanie, naukę. Wynikało to oczywiście z obowiązującej wówczas normy kulturowej, według której czytanie i lektura były nieodzownym elementem miana człowieka wykształconego, kulturalnego. Tak więc m.in. o swoim pobycie w Choczu napisał tak: „Jeszcze tu o Choczu powiedzieć muszę, że temu miejscu winienem całą zasadę losów moich dalszych i dokończenie poniekąd mojego wychowania, bo w tej ciszy, oddalonej od rozrywek i zgiełków, cały się przyłożyłem do nauk i do czytania ksiażek, które się w bibliotece tej kolegiaty znajdowały"

Na kartach wspomnień Pstrokońskiego niezbyt często pojawiają się opisy dotyczące członków jego rodziny. O ojcu pisze tylko jeden raz, w związku z jego śmiercią, nie podając nawet pewnej daty zgonu: „Wkrótce potem ojciec nasz w Masłowicach umark, pochowany w Wieluniu u OO. Reformatów, jakoś roku 1720 "33. Matkę wspomina kilka razy, z tym że relacje te mają różny charakter, np. opisując trudne i biedne dzieciństwo przywołuje taki obraz: „Kawałek sera i chleb, to [był] najmocniejszy posiłek. Na to nie zważając, tęskniło się do szkoły, a matka dobra, gdy mię widziała dotkliwego na sukienkę podłą, mawiała mi często: 'Chodź teraz w płachcie, będziesz potem chodził w hafcie'. Co się ziszczyło!" ' Natomiast w innym miejscu stosuje konwencję, która przypomina hagiografię: „Ta matka nasza pełna była świątobliwości: modlitwą i postami zyła, nikogo w życiu słowem nie obraziła, miała od Boga dar leczenia chorych, o kilka mil do siebie się uciekających, prostymi wódkami i mastykani, które robiła; chmury i nawałnice krzyżem św. rozpędzała" ${ }^{35}$.

Spośród rodzeństwa (miał dwóch braci i jedną siostrę) opowiadla ksiądz Pstrokoński historię brata Franciszka, który zaginął we wczesnej młodości i po latach odnalazł się, ale ży z żoną i trojgiem dzieci w strasznej biedzie. W związku $z$ tym - jak miłość chrześcijańska każe - ksiądz oddał mu w dzierżawę wieś Gazdowo, należącą do posiadanej przez niego kanonii kaliskiej. Było to postępowanie niekorzystne dla księdza, ponieważ dzierzawiący Gazdowo, niejaki pan Żolądkowski płacił corocznie 1000 zlotych. Opowiadlanie o bracie kończy ksiądz Pstrokoński słowami: „Nad tym artykułem zastanawiam się. Czyli mało miałem do myśli? Natenczas kiedy pusto w kieszeni, trzeba bylo radzić o synowcu ${ }^{36}$ i o bracie Franciszku z żoną i dziećmi, ale Bóg miłosierny wszystko opatrzył"37.

Sprawy finansowe zajmują dosyć dużo miejsca w relacji Pstrokońskiego $z$ reguły są to żale na brak pieniędzy, ale nie są one nacechowane emocjonalnie, zawsze znajcluje on jasny płomyczek, podpierając się pomocą opatrzności Bożej. Rezydujencję przy kolegiacie w Choczu, opisał Pstrokoński tak: „Kanonikowi tam dochodu na dzień nie przychodzi tylko złotych trzy, a prałatom, jako to dziekanowi i kustoszowi po złotych 3, groszy 12 bez pieniążka. Są tam jeszcze oprócz tego dystrybucje funduszowe, anniwersarze i msze, ale za to mało co na 
rok na osobę przychodzi. Z tego prowentu żć za grosz, żeby wystarczyły na dzień złotych trzy, trzeba dobrej ekonomii, aby się samoczwart wyżywić: bo bez służącego, bez stangreta, bez usłużenia do kuchni nie można się było obchodzić. Aleć o to wszystko myśl moja się nie zatrudniała, bo zawsze była na pogotowiu opatrzność boska, ta mi clała wystarczać i na własne potrzeby i na wychowanie synowca mego i na matkę i na plebanię mokrzką, o której powinnością moją nie było zapominać"38.

Nie zawsze jednak musiał liczyć tylko na Opatrzność, kiedy bowiem otrzymał nominację na plebanię w Mokrsku, to musial pojechać do prymasa Teodora Potockiego do Łowicza, jednak: „Na drogę nie było pieniędzy, trudno je było znaleźć w domu matki mojej, przecież znalazłem je u mojej ciotki Pstrokońskiej. Ta pani pierwsza była i ostatnia $z$ familii mojej do poratowania mnie w potrzebie, bo mi pożyczyla na drogę łowicką czerwonych złotych pięć na moją kartę, ale nie mając skąd ich oddać, mszami świętymi wypłaciłem się jej"39.

Opatrzności przypisuje również Pstrokoński to, że znajdował na swojej drodze ludzi, którzy chętnie służli mu pomoca, byli instrumentem niepoślednim tej opatrzności, jak np. Potocki, wojewoda wołyński: „Ten pan tyle miał względu na mnie, że mi przez umyślnego posłańca, $z$ Podola do Chocza wyprawionego, ofiarował jakie tylko mógł mieć w wielkich swoich włościach najlepsze beneficjum, że mi się oświadczył swoim kosztem posłać mnie do cudzych krajów. Ale tego dwojga nie było woli Pana Boga, żebym przyjął, że na ostatek równal mię w afekcie swoim $z$ dziećmi swojemi. Otóż to były opatrzności Boskiej drogi i sposoby do pomocy, ratowania mię za szczupły chleb, którym się przy kolegiacie chockiej kontentowałem (...)"40"

Warto zwrócić uwagę na stylistykę przytoczonego ostatnio tekstu Pamiętników. Pstrokoński wyraźnie wskazuje, że jego życie przebiegało zgodnie z wolą Boską, że nic nie mogło mu się przytrafić, jeżeli opatrzność nie pozwolila na to. Chociażby najmożniejsi świata doczesnego podejmowali korzystne i ważne dla niego zobowiązania, to jeżeli nie były one zgodne $z$ wolą Najwyższego, to i tak nie dochodziło do ich realizacji.

Co więcej, Pstrokoński na kartach swoich wspomnień, zgodnie z nauką Kościoła, przedstawiał się jako czlowiek skromny, nie dbający o własne interesy, $z$ pokorą godzący się na wszystko co los przynosi. Jak informuje nas w swoich wspomnieniach: „(...) a o promocje nie dbałem. Miałem sobie zadosyć $z$ lkanonika na kustosza, potem dziekana postąpić"41. Nawet najwyższa dla niego godność - kanonika gnieźnieńskiego - była dla niego „wielkim zaskoczeniem”: „Nadeszła ostatnia epoka promocji mojej, do której mię Boska opatrzność przeznaczyła, a której kresu wymierzonego już się nie godziło przestąpić: roku 1765 nie zabiegającemu, nie proszącemu, nie spodziewającemu się nawet i nieprzytomnemu ${ }^{42}$, dał mi mój Pan kanonię gnieźnieńską" ${ }^{43}$.

Z takich samych powodów - jak wynika $z$ Pamiętników-Pstrokoński z cierpliwością znosił cierpienia, które opatrzność na niego zsyłała: „Rokiem przed tą jego śmiercia" ${ }^{44}$, "gcly przez funduszową wieś owej kanonii przejeżdżałem, podobało się Bogu zaprawić gorzkością tę moją koadiutorię, bo w Krzywinie na Piekłach (miejscu tak nazwanem) konie mi się zbiegały, woziciel i służący z kolaski pospadali (...). Ja, tak dla poradzenia sobie, wyskoczyłem $z$ niej, ale nieszczęśliwie, bom nogę lewą nad samą kostką złamał (...)" ${ }^{45}$. Po opisie wszystkich cier- 
pień, związanych $z$ nastawianiem i kurowaniem złananej nogi ksiądz dodaje: „Całuję rękę Boską, która mnie wychłostała po kościach moich i na nich mię uzdrowiła, umartwiła i ożywiła" ${ }^{\text {. }}$.

W jednej tylko sytuacji Pstrokoński nie chciał poddać się dyspozycji swojego protektora, mianowicie, gdy prymas Łubieński zamierzał mianować go oficjałem i wikariuszem generalnym in spiritualibus: „Ta wola prymacyjalna była piorunem dla mnie lękającego się zawsze sędziowskiej władzy w najdelikatniejszym punkcie sumienia, a to w sprawach rozwodowych, które już na ten czas wszczynały się i mordowały sądy i trybunały duchowne, substancje szlacheckie niszczyły, świętokradztwa w sakrament małżeński wprowadzały i drogę bitą na potępienie piekielne torowały, a to $z$ samej jedynej przyczyny bezecnych i skażonych kobiet, bo mężowie prawie nigdy, a jeżeli kiedy który, to ledwie setny mąż i to nie tak promował, jako bardziej, iż musiał pobłażać na taki niegodziwy rozwód złej żonie swojej. A to powietrze zajęło się najpierwej w wysokich familiach, od nich zaraziły się damy godne ziemiańskie, na ostatek to zlo postąpiło do miast wielkich i małych, a nawet do ubogich chat. Więc trwożąc się być arbitrem takowych sporów wymawialem się panu mojemu od tego jeneralnego oficjalistwa i wreszcie odsunąłem się od niego. Nie wiem, czy politycznie, bo nie czekając na instrument $z$ kancelarii, wsiadłem do powozu i tak mówiąc ucieklem ze Skierniewic" ${ }^{47}$.

Przytoczony ostatnio fragment wypowiedzi Pstrokońskiego jest istotny również $z$ tego powodu, że pokazuje jego stosunek do kobiet, który byl charalkterystyczny dla ówczesnego duchowieństwa. Zclaniem księdza, podstawową winę za rozpad małżeństwa ponosila kobieta, ponieważ mężczyzna - nawet jeżeli wnosil sprawę o rozwód - to i tak czynil to $z$ podpuszczenia żony. Pstrokoński nie bierze pod uwagę faktu, że większość malżeństw zawierano wówczas z racji majątkowych, rodzice decydowali o losie córki, nie biorąc pod uwagę jej zdania. Nic więc dziwnego, że takie małżeństwa nie mogły być trwałe. Wzrost liczby rozwodów $-z$ winy kobiet, jak twierdzi ksiądz - jest więc też dowodem wzrostu świadomości poczucia własnej wartości u płci pięknej.

Styl hagiograficzny stosuje Pstrokoński w odniesieniu do osób, które lubi, bądź które promowały go, a do takich należał kanclerz wielki koronny, biskup poznański, Andrzej Młodziejowski ${ }^{48}$. W ten oto sposób opisuje fragment jego losów: „Podawała mu się okazja do wzięcia probostwa płockiego, a to przez koadiutorią od Miaskowskiego, kanonika gnieźnieńskiego, u którego niegclyś był kapelanem, ale się to P. Bogu nie podobało, i owszem dla zasługi jego przez cnotę cierpliwości dopuścił tego Pan Bóg, że go niegodziwie zelżono i spotwarzono (nie wspominam kto) listami szkaradnemi. Dopuścił P. Bóg na niego umartwienie takie, które by kogo innego do grobu wpędziło. On je zaś przyjął $z$ zimną krwią, tylko na ulgę swojego serca panu swojemu i mnie dal do czytania te paszkwilujące siebie listy i obelgi. Tak nie dostąpił on swej wspaniałej koadiutorii, która się dostała Szembekowi, teraźniejszemu biskupowi płockiemu. On zaś, jako prawclziwy Chrystusów naśladowca, nie tyllko złym za złe nie oddlawał, ale im sluzył i pomagał $\mathrm{z}$ moim wielkim podziwieniem i przykładem. Tak wyćwiczony, $z$ dekretu Boskiego nagrodzony wkrótce został, gdy po koronacji króla Stanisława, był przy prymasie niejako sprężyną rządu” “9 . 
Jak przystało też tak znakomitemu i zasłużonemu człowiekowi: „Śmierć tego pana, któremu czerstwość jego dlugie życie obiecywała ${ }^{50}$, nie była bez okazji. Przysądził on w sądach swoich bardzo sprawiedliwie podsędkostwo pewnemu ziemianinowi, przeciwko drugiemu, którego dwór protegował. $Z$ tej okazji martwiony był bardzo u dworu (czego potem nieznośnie król żałował). Z tego umartwienia wpadl w chorobę, $z$ której już nie wstał. (...) To był też bardzo cnotliwym i pobożnym kapłanem i biskupem, który nie religię do polityki, ale politykę do religii stosował, a przynajmniej umiał jednoczyć sacerdotium cum imperio"51. Pstrokoński nie przyjmuje też żadnych krytycznych uwag pod adresem Młodziejowskiego. Polemizując $z$ głosami dezaprobaty na jego temat, odpowiada m.in. tak: „Krytykują drudzy, że zbiory jego w dobrach, sumach, ruchomościach nie wiedzieć gdzie się podziały. Ale cóż stąd logilka wnosi? Jeżeli pozostała po nim fortuna zatrudnia dotąd sądy i trybunały, to nie jest winą dawcy, ale jest wadlą wszystkich ziemskich rzeczy; nie wiecznych, bo doczesnych, przez które w familiach nawet monarchicznych upadają fortuny, więc nie dziw, że i w familiach polskich upadlają" ${ }^{52}$.

Rozdział VIII i IX Pamiętnilków księdza Pstrokońskiego zajmuje opis podróży do Włoch i pobytu w Rzymie. Analizując te dwa rozdziały, można zauważyć, że stosuje w nich ksiądz trochę inną stylistykę i inny język. Zdając relację ze zwiedzania kolejnych miast, rzeczowo opisuje, co mu się tam podobało, co budziło jego dezaprobatę, jakie zauważył różnice między polskim a zagranicznym życiem codziennym. Jak wiemy, Pstrokoński wyjechał do Rzymu jako clelegat kapituły gnieźnieńskiej w jej sprawie $z$ zakonem bożogrobców o szpital ${ }^{53}$. Tylko na początku swojej relacji posługuje się stylem znanym $z$ poprzednich rozclziałów Pamiętników, pisząc: „Po zakończonym trybunale nadszedl rok 1768 (...). Podobało się tejże kapitule [gnieźnieńskiej], na popieranie tej sprawy, posłać mię do Rzymu. Bóg mi ku starości już dążącemu, bo lat natenczas już mającemu 55, użyczył tę laskę, bom zawsze pragnął nawiedzić to miasto święte, skropione krwią tylu męczenników i zaszczycone zwłokami ich, a w szczególności grobami książąt apostolskich, Piotra i Pawła (...)"54.

Dalej już następuje rzeczowy opis tego co zabrał w drogę, w jalki sposób i dlaczego wybrał sposób podróżowania: „Wziąłem ja z sobą lokaja, już mi od lat dwóch służącego, Polaka, nie umiejącego, równie jak ja, tylko po polsku; wziąlem dwie pary sukien porządnych, jedną z kalotu brukselskiego, drugą na sobie popielatą, $z$ sukna francuskiego i płaszcz $z$ wilkami na zimny czas oraz koszul tuzinów dwa. Wziąłem trzos siedmiuset dulkatów napelniony i tekę z papierami. Nic więcej nie wziąłem, nawet ani pościeli, tylko wielkie prześcieradlło, abym się nim obwijał, dla ochronienia zarazy w pościelach austerników zagranicznych. (...) Z Wroclawia dnia 27 kwietnia wyjechalem, już nie furmańską karetą, co tydzień do Wiednia chodzącą, bo tam się mieszczą różnego gatunku ludzie. Tam wsiędzie Żyd i Żydówka, i ten i ten, taka i owaka, a wlecze się powoli jak smoła i niezmiernie trzęsie, i lubo ten przejazd jest bardzo tani, ja jednak na pocztę, choć bardzo drogą, ale z pojazclami bardzo wygodnymi wsiadlem i traktem na Opawę, Ołomuniec i Bryn jechałem. We Wiedniu, po wyjeździe $\mathrm{z}$ Wrocławia, czwartego dnia stanąłem" ${ }^{55}$.

Wiedeń zdecydowanie nie przypadł clo gustu kanonikowi gnieźnieńskiemu, chociaż potrafił docenić niektóre jego dobre strony: „Stanąłem w Wiedniu 1 ma- 
ja w najwspanialszej austerii, gdzie taniość większą niż w Polsce zastałem. Obiad smaczny i bażanty smaczne; wino austriackie, w złotym kolorze, dobre, a na wpół tańsze niż francuskie, bo tam węgierskie są zbyt słodkie. (...) Tymczasem wiedeńskie osobliwości oglądałem, gdzie nic mi się nie podobało wyjąwszy niezmiernie wielki kościół katedralny i wieżę na boku kościoła przecudowną, bardzo wysoką, $z$ ciosowego kamienia stawianą, ale tak, że od fundamentów szerokość jej jest obszerna, wyżej węższa, a na ostatek wierzchołek jej najwyższy samym tylko zasklepia się krzyżem, zaś kościół pod dachówką wewnątrz okopciały, bez ozdoby. Loża cesarska przypięta wysoko do filaru, na którą trzeba się piąć, jak po drabinie. (...) Miasto cienne, bo ma kamienice wysokie, o 6, 7 i 8 kondygnacjach, ulice błotniste i bardzo ciasne, oprócz jednego placu (bo się rynkiem nazwać nie może), na którym stoi fontanna i statua Leopolda cesarza, dziadla naszej świątobliwej pani, żony Augusta III. O zamku cesarskim dobrze napisal jeden jeograf, że piękniejsze, wspanialsze, bogatsze są stajnie królewskie w Wersalu niz ten zamek. Lustrowałem go (...). Widziałem sale obszerne, ale nic $w$ nich nie widziałem, co by godne było wiclzenia. Pałace wiedeńskie względem palacy warszawskich małą są rzeczą. Kaplica zamkowa niknie w proporcji kaplicy królewskiej w pałacu saskim warszawskim" ${ }^{\text {55 }}$.

Z Wiednia udal się Pstrokoński do Wenecji, gdzie $z$ kolei nie smakował mu się chleb, chociaż starał się zrozumieć podstawy takiego stanu rzeczy: „Chleb tak w tem mieście, jako tez w całem państwie weneckim tak twardy, jak kamienie, bo ciasta nie ruszają. Rozumiem, ze robią to $z$ prawa rządu, aby ludu nie oszukiwali piekarze nadęciem chleba drożdżami, albo potażem, lub wapnem" ${ }^{\text {" }}$.

Z Wenecji udał się Pstrokoński do Padwy: „Wsiadłem na statek wielki i pły. nąłem przez laguny, czyli niegłębokie morze, a potem lądem przyjechałem do Padwy o mil polskich pięć od Wenecji odległej. Tam zastałem wielką taniość żywności, dobry w austerii obiad i wieczerzą, które ze mną jadł tameczny penitencjarz, franciszkanin i szlachcic polski z krakowskiego (bo dla Polaków zawsze tam jest penitencjarz Polak). Nawiedziłem tam cudownego świętego Antoniego kaplicę i ołtarz, na którym wystawiona jest trumna wielka srebrna"58.

Następnie odwiedził Bolonię, która „(...) po Rzymie w stanach papieskich najsławniejsza i najludniejsza, bo w znacznej części złożona jest $z$ pałaców, które zamieszkują panowie wielcy, a te pałace są ozdobione perspektywami i lantszatami, wynalazkiem matematycznym. Gołębięta po bonońsku karmione wszystkie smaki w jedzeniu przewyższają ${ }^{59}$. Nie mógł też nie odwiedzić hodowli słynnych piesków bolończyków: Tutaj to stolica na te pieski tak ulubione od Polaków. Przez ciekawość byłem u jednej madame, czyli ochmistrzyni tych piesków bonończyków. Była tam sala na sto gniazd i cała napełniona. Każde psiątko leży w swoim koszyku mięlkko wysłanym, ale nie chciałem tego specjaliku, a raczej smrodu drogo kupować"

Przy okazji opisu wizyty w Bolonii, możemy też po raz kolejny obserwować stosunek Pstrolkońskiego do kobiet, kiedy stwierdza, że zamiast kupować pieski: „Wolałbym był widzieć i mówić $z$ jedną panną mistrzynią w każdej nauce w akademii bonońskiej i jubilatką laurów doktorskich, ale nie chciało mi się słuchać mądrości kobiecej za moje własne pieniądze" ${ }^{\text {"1 }}$.

We Florencji za godne uwiecznienia uznał spotkanie na ulicy Polaka, które opisuje w tych słowach: „Tu mi się trafiła szczególność godna pamięci. Idąc 
ulicą obszerną, widzę kawalera naprzeciw mnie idącego, $z$ przeniknieniem się i radością ręce wyciąga, a nie wiedząc przedtem o sobie, jakbyśmy się znali, kto jesteśmy, witamy się polskim językiem, ścisnęliśmy się serdecznie. Powiadam mu kto jestem, on mi też powiada kto jest. Był to szlachcic śląski od granicy ziemi wieluńskiej zwany Strachwitz (...), trzydzieści lat w wojsku florenckim służący: natenczas był kapitanem gwardii. Tak dobrze mówił po polsku, jakby dopiero dziś z Polski się wyniósł"

Oglądając miasto stwierdził, ze florencki kościół katedralny ${ }^{63}$ jest jeszcze wspanialszy niz w Wiedniu i: „mogę śmiało rzec, że dwa razy nad nasz gnieźnieński wyższy i większy" ${ }^{\prime \prime}$. Nie spodobały mu się zaś pałace książąt llorenckich: „Lustrowałem zamek starodawny książąt florenckich ${ }^{65}$; w nim nic nie masz, ani struktury, ani piękności, oprócz, że w jednej sali niezgrabnej, sufit miejscami upstrzony jest blaszkami szczerozłotymi. (...) Więc miałem wolność lustrować pałac nowy, nawet być w sypialnym pokoju książęcym. Pałac ten nie jest szczególniejszym. Porlobny jest w galeriach do zamku krakowskiego, ale go zamek krakowski $z$ wspaniałości swojej bardzo wiele celuje" ${ }^{66}$.

Gdy z Florencji jechał drogą przez Witerbo do Rzymu zauważył z przekąsem: „(...) lubo pola i role są równe i prawie ziemia może się nazwać ziemią obiecaną, a przecież Włłochów lenistwo sprawia, że nie orzą, nie sieją, tylko się gnuśni cisną do miast, około których tylko winnice i oliwne i morwowe hodują drzewa" ${ }^{67}$.

Do kresu swojej drogi - Rzymu - przybył Pstrokoński po przeszło miesiącu podrózy, w pierwszych dniach czerwca i - jak skrupulatnie odnotowal - koszt jej $z$ Gniezna wyniósł 100 czerwonych złotych ${ }^{68}$. Zamieszkał najpierw w Hospicjum San Stanislao dei Polacchi i tam przyjmował rodaków, którzy wówczas przebywali w Wiecznym Mieście, a ich liczbę określił na 70 osób - kanoników, kapłanów, kleryków, zakonników.

Swoje zajęcia w Wiecznym Mieście w skrócie kanonil gnieźnieński opisał tak: „Zabawy moje były w tym świętym mieście, obchodzenie kościołów prawie co dzień, a najczęściej watykańskiego, z jezuitami przyjaźnienie się, od którego jenerała godnego i świątobliwego odebrałem dyplom na uczestnictwo $z$ jego zalkonem sufragiów, które nie zwykły bywać komunikowane, tylko udzielnym książętom. (...) Palace rzymskie zwiedziłem osobliwie wtenczas, kiedy cały prawie Rzym wyjeżlża na kampanije ${ }^{69}$, to jest na wolniejsze powietrza użycie podczas (jak zowią) wiledziatury ${ }^{70}$, która się zaczyna od połowy września i ciagnie więcej nad miesiąc. (...) O teatra i komedyje, jako te nie są przyzwoitym obiektem dla duchownego, tak cale nie dbałem"71.

Długo Pstrokoński nie mieszkał w polskim Hospicjum, ponieważ: „W Domu tym naszym nacjonalnym nie mieszkałem tylko ćwierć roku, bo dla zamkniętego w nim powietrza nie clobrze mi w nim było. Zgodziłem więc stacją na miesiąc za szkudów piętnaście, które czynią czerwonych złotych pólósma, a to $z$ apartamentem dla mnie pięlknym, obiciami, meblami, pościelą zawsze białą i czystą, z praczką, obiadem i wieczerzą aż nadto hojnemi, ale jednak lokaj musiał rozporząlzać w kuchni gotowanie do polskiego smaku"72.

Cała wyprawa Pstrokońskiego do Rzymu, łącznie $z$ podróżą trwała prawie rok. Jako Polak, przyzwyczajony do dużo zimniejszego klimatu ze zdziwieniem przyjmował reakcje Włochów na chłodniejszą pogodę, pisząc w ten sposób: 
„Okna zawsze miałem w dzień otwarte, bo za mojej bytności nie było w Rzymie ani śniegu, ani zimy, tylko przez trzy dni nowego roku byl nie mróz, ale mały mrozek, który zważył małe sopelki wody na fontannach. I dziwowałem się, gdy Włocha, a jeszcze bardziej, gdy Polaka drżącego od zimna widziałem"73.

Opisy zawarte w Pamiętnikach świadczą, że Pstrokoński był bardzo uważnym obserwatorem, interesował się wieloma aspektami życia i mimo, ze nie znał języka włoskiego przedstawił bardzo dużo, trafnych spostrzeżeń i to takich, których inni nie prezentowali.

Sporo miejsca w jego opisach zajmuje jedzenie, $\mathrm{i}$ w związku $z$ tym $\mathrm{m}$. in. $z \mathrm{a}$ uważa co następuje: „Nie zaniedbałem przezierać jatek mięsnych, rybnych, leguminowych, ptasznych, magazynów zboża, siana, a na te porządne dyspozycje patrząc wzdychałem - 'O tu wszystkiego dobrego są przykłady! Wszystko przednie!'. I niech mówi kto chce, taniej tu żywność się kupuje niż we Wrocławiu, niżeli w których mniejszych miastach polskich. Funt mięsa wołowego po groszy polskich 8 i 9 . Ale jakież to mięso? Pod względem naszego, jak bażant do kury, smaczne, a smakiem kraju swego szczególnym, słodkim i miłym, tłuste, ale nie taką tłustością łojową, jak u nas, lecz tłustością nieznacznie przenikającą całą masę mięsa. Ryby morskie wyśmienite" ${ }^{\prime 74}$.

Jedno mu się nie podobało w menu wloskim: „Pająków tylko morskich ${ }^{75}$, choć te są specjałem dla Włochów, cierpieć nie mogłem, raz tyllko spojrzawszy na nie rozpłatane jak szczury" ${ }^{76}$.

Ponadto kanonik gnieźnieński zauważył, że: „Gęsiami Włochy się brzydzą $\mathrm{i}$ ich nie jedzą, ale za to indyków pewnie sam Rzym więcej poje, aniżeli cała Polska. Niezmiernemi stadami przypędzają ich z Obojga Sycylii do Rzymu, a poganiają je długimi na 4-7 lokci błotnistymi trzcinami $z$ kitką na końcu"77.

Duże uznanie w kanoniku gnieźnieńskim wzbudziło wino, które można było konsumować w Rzymie: „Win wielorakie są gatunki: włoskie, neapolitańskie, florenckie (...), jednak najlepsze dla nas Polaków z powiatu papieskiego d'Orvieto, wypili go u mnie Polacy i poniekąd Włochy przez trzy kwartały, na 200 butelek. Butelka $z$ czystego, cienkiego szkła, w którym jest blisko półtory kwarty wrocławskiej ${ }^{78}$, płaci się po jednym złotym polskim" ${ }^{79}$.

Bardzo dobre mial też zdanie o Rzymianach: „Ludzkości rzymskiej wychwalić dosyć nie można. Doznałem jej po wiele razy. Gdy idącego napadła potrzeba, juz ci domyślny Włoch wypada $z$ botegi i woła 'Oto tam mości panie iść potrzeba' i sam na miejsce zaprowadzi. Gdy deszcz zaskoczy to prosi, aby się schronić do jego pięknej botegi, albo też bierze parapluie, to jest baldachimek i zaprowadza do stancji” ${ }^{80}$. Co więcej za usłużność wobec cudzoziemców Rzymianin: „Za tę fatygę małą płacą się kontentuje" ${ }^{11}$.

Zdaniem kanonika gnieźnieńskiego, szczególną sympatią darzyli mieszkańcy Rzymu właśnie Polaków: „Ludzkość w Rzymianach nie porównana $z$ innymi narodami. Znałem kilku Polaków, $z$ których każdy pozapożyczał się po kilkaset dukatów, po lat kilku oczekiwali cierpliwie przywrócenia sobie długu. Ja za jednego założyłem, a u drugich poprzepadało, ze wstydem dla kraju naszego. Nawet u rzymskich Żydów znajdzie tę ludzkość, kiedy mi jeden tego narodu kupiec dawal na kredyt dziesięć tysięcy szkudów, które wynoszą sto tysięcy złotych polskich. Czyliż się znajclzie w innym narodzie takowa uczynność? Ale nie tylko to: Jest coś sympatycznego w Rzymianach ku Polakom, że w nich nie cenzurują 
defektów, nawet ich nie widzą. O pielgrzymie Polaku pijanym nie mówią, że to Polak, ale że Niemiec 'Tedesco ubriaco'. Czyliż też w nich znajduje się miłość prawdziwie chrześcijańska, że ustępują i przebaczają ułomności ludzkiej, co dowodzi przypaclek następujący. W sprawie, którą mial z biskupem jednym o jurysdykcją pewny klasztor, zastałem w Rzymie prałata, infułata tego klasztoru $z$ trzema, czy czterema zakonnikami swymi. Prałat ten (był to Polak) tak się raz upił, że $z$ nóg spadł i na bruku na ulicy jak nieżywy leżał. Najeżdża go natenczas kareta kardynalska, stangret zsiada $z$ kozla, ogląda, chce go trzeźwić, ale wi$\mathrm{d} z a ̨ c$, że nie jest zemdlały, tylko opiły, bierze go za pomocą inszych, wsadza do karety i zawozi do klasztoru bliskiego zakonu jego, poznawszy $z$ odzienia jaki był zakonnik. Dobry ten stangret nie głosił tego trafunku, nie obgadywał pijanicę Polaka, cyt wieczne" ${ }^{83}$.

Podczas swojego pobytu w Rzymie Pstrokoński systematycznie zwiedzał miasto, jak już wcześniej napisano, głównie kościoły, ale nie tylko, ponieważ zanotował kilka ciekawostek o miejscach świeckich, np. o Piazza Navona: „Drugi zaś plac, albo rynek, zowie się Piazza Navona ${ }^{84}$, wśród którego są trzy przedziwne fontanny. Te jak otworzą, tak pręciuteńko cały ten plac zatopią wody, miejscami na łokieć, miejscami na półtora łokcia wysoko, a otwierają je w miesiącu czerwcu, lipcu i sierpniu. Tam się zjeżdżają Rzymianie i $z$ okolicznych domów patrzą na miły potop, inni na pobrzeżach wysoko pod kamienicami wymurowanych, stoją. Wszyscy z tej wody chłód w siebie ciągną i duchy swoje ożywiają, a karety $z$ końmi po tej żywej krynicy przechodząc się tam i sam brodzą, a tym sposobem powietrze schładza się i czyści" ${ }^{85}$.

Zwiedzając miasto, jako duchowny, powoływał się na słowa papieskie: „Klemens XIV papiez $\dot{z}$ listach swoich już po polsku tłumaczonych napisał, że choćbyś mieszkał w Rzymie sto lat, co dzień w nim co nowego obaczysz. Niech to będzie hiperbolą i egzageracją. Co do mnie, szczerze wyznaję, że ustawicznie bywając w kościele Świętego Piotra, w nim dziś widziałem, czego wczoraj nie, i tak dalej. Co dzień mi się zdawal bogatszy, co dzień osobliwszy, co dzień cudowniejszy. Nigdy zadość oczu, serca, cielkawości, ukontentowania ludzkiego nie nasycający, jakby był nie rąk ludzkich, ale Boga samego dziełem"86.

W ramach swoich refleksji a propos podróży do Włoch, przedstawil Pstrokoński takie - dosyć krytyczne - zclanie: „W tym pobycie moim w Rzymie przekonałem się, że tylko tacy Polacy, co już w Ojczyźnie się wydoskonalili jeździć do Włoch powinni, bo ci, którzy to tylko trochę laciny, trochę logiki liznęli w kraju swoim, hańbią naród swój i tam się niczego nie uczą, bo o sobie wysoko rozumieją, jakoby już z zupełną sapiencją do Rzymu przywędrowali, a oni stanu ojczyzny swojej nie znają. Wszystka ich zabawa, teatra, przechadzki, a co gorzej podchodzenia swoich ziomków w kanoniach i beneficjach, plotki i potwarze na swoich rodaków: oto jest cały ich zagraniczny polor. Znałem i znam powróconych stamtąd i zdumiewam się, jak mogli zostać kapłanami, choć ad Solam Missam, bo pierwszych początków teologii nie znają, ani Corpus luris, to jest prawa cywilnego i kanonicznego tak, żeby ich trzeba na naukę $z$ gruntu do naszych seminariów odsyłać. Strzegłem ja się $z$ takimi półgłówkami, młodzikami, mieć sprawę, albo im poufać. Dobra rzecz młodego posłać do Rzymu, ale go trzeba oddać do jakiego kolegium, zeby byl pod profesorami i pod karnością. 
Znałem i znam takich, którzy w nich po lat kilka byli i stali się kościolowi i ojczyźnie użytecznymi”"87.

Rzym był dla Pstrokońskiego z natury rzeczy dobry, nie mogły mieć w nim miejsca żadne złe zdarzenia, ani przypadki, czego ilustracją mogą być następujące wersy Pamiętników: „Rzymu jak puszczy jakiej jest wielka rozległość, trafiało mi się milę włoską jedną i drugą schodzić, wizytując jakie miejsca święte i spóźnić powrót aż do ciemnej nocy, jednak nigdy nie trafiłem na napastnika. Stąd się pokazuje fałsz potwarzy, którą roku przeszłego ${ }^{88}$, znać z podania nieprzyjaciól stolicy apostolskiej, wydrukował Pamiętnik Warszawski jakoby za panowania teraźniejszego papieża Piusa VI pozabijano w Rzymie samym, dwadzieścia tysięcy przeszło ludzi" ${ }^{89}$.

Ponadto zdumiewała go taniość panująca w Wiecznym Mieście, którą często przeciwstawial znanej mu z Polski drożyźnie: „Odzienie w Rzymie może być bardzo tanie, bo tam pełno jest nowych prawie sukien, $z$ pięknych rozmaitych materii, które po prałatach, kawalerach, przedawają, byle mieć wiaclomość, żeby nie po suchotnikach. (...) Zdumiewała mię też tamtejszych osłów taniość; za złotych polskich 7 lokaj mój kupił osła, którego znów odsprzedal" ${ }^{90}$.

Również panujące tam zwyczaje przyjmował ze spokojem, realnie oceniając ich wartość: „Wizyty z godnymi ludźmi tu cóżkolwiek kosztują, bo na początku sierpnia, na początku nowego roku, na imieniny obsyłają się komplementami i płaci się lokajowi, który przychodzi od pana swego $z$ tą ceremonią, zowie się to mandzia. Takież mandzie płaci się burgrabiom jałacowym, którzy po wszystkich apartamentach panów swoich, wojażującego oprowadzają i okazują owe splendory, obrazy i prawie cuda w osobliwościach znajclujące się: ale te mandzie, ta zapłata nie jest kosztowna. Polskie usłużenia, choć niewiele warte daleko więcej wyciągają"91.

Jednak w końcu nadszedl czas powrotu do Ojczyzny. Pstrokoński tłumaczy ten fakt w następujący sposób: „Tymczasem wybuchła w Polsce konfederacja barska, skąd mię też przyszło pomyśleć o śpiesznym do kraju powrocie. Zakochanie się moje w świętym mieście Rzymie wiązało mię w nim zamieszkać, bo nie tak w tym słowie Roma znajdują się anagramatyczne slowa 'amor'92 i 'mora's3 jako w sercu i chęci tego, kto pozna Rzym. Ale trzeba było ustąpić potrzebie. W Rzymie żyć $z$ kwesty i jałmużny, już mój stan nie dopuszczał, a $z$ ojczyzny weksle odbierać, pustoszenie jej, żadnej mi nadziei nie czyniło"94.

Uzasadnienie kanonika gnieźnieńskiego, dotyczące powodów powrotu do kraju nie jest przekonujące - konfederacja barska wybuchła bowiem już w $1768 \mathrm{r}$., w lutym, kiedy Pstrokoński miał zamiar dopiero wyruszyć w podróż clo Rzymu, a nie w 1769 r., kiedy musial wracać. Zapewne więc podal taki powód jako bardziej poważny, niż fakt, że właściwie jego misji rzymskiej nie udało mu się szczéśliwie zakończyć ${ }^{95}$. Tłumaczenie, że nie chcial narażać Ojczyzny na straty, wynika z przyjętego stylu opowieści o własnym życiu.

Tak więc z Rzymu wyjechał Pstrokoński 5 marca 1769 r. razem $z$ księdzem Dembińskim, synowcem wojewody krakowskiego. W ostatnich dniach pobytu w Rzymie, obejrzał jeszcze loże dla kardynałów, przygotowane na conclave, po śmierci papieża Klemensa XIII ${ }^{96}$, pożegnał protektora polskiego kardynała Albaniego oraz inne ważne osobistości i przyjaciól. Dwaj duchowni wracali jed- 
nak inną drogą niż w czasie podróży do Rzymu, ponieważ Pstrokoński chciał odwiedzić Loreto $^{97}$.

Bazylika loretańska nie zrobiła na kanoniku gnieźnieńskim dużego wrażenia: „Kościół ten loretański opodal trochę od miasta stoi, wielki, z kaplicami wkoło, ale w strukturze nie jest osobliwszy, więcej o nim rozumiałem ${ }^{98}$. Odnotował tez akcenty polskie odnalezione w bazylice: W kaplicy przed ołtarzem Matki Boskiej widziałem lampę serce, szczerozłotą, którą przed kilku laty przytomny tam książę Radziwiłł oddlał na ofiarę Matce Boskiej. W skarbcu zaś cały garnitur aparatu, samymi uryjańskimi perłami wysadzanego, dawno kiedyś ofiarowała dama polska" ${ }^{99}$.

Pozytywne wrażenie natomiast na nim zrobili ludzie zamieszkujący tamten region: „Kraj ten i caly markizat ankonitański jest bardzo tani, obfituje w woski i wszelaką żywność, a w prostym stanie celuje w uczciwości, w odzieniu, w manierze grube chłopstwo inszych państw włoskich, bo jeszcze grubsze nad krakowskich, podlaskich i mazowieckich wieśniaków"100.

Zostawiając, trochę rozczarowany, Loreto, 12 marca 1769 r. dotarł do Ankony, gdzie - jak się wyraził - „lustrowałem port bardzo sławny, który mieści się w liczbie czterech na świecie szczególności, według przysłowia: „Una fides romana, unus pontifex in Roma, una libertas polona, unus portus in Ancona"101.

Następnym miejscem postoju było Rimini, które bardzo przypadlo do gustu Pstrokońskiemu: „Miasto to jest bardzo wesołe i wielkie: place, rynki, domy publiczne są wspaniałe, kościół franciszkański lubo bez podniebienia ${ }^{102}$, tylko pod dachem, ale ma $w$ facjacie kościelnej wielkie, wysokie arkady $z$ najprzedniejszych marmurów. Godne też są widzenia i podziwienia sztuki, które starożytność wiekom teraźniejszym do naśladowania podała"103.

W clrodze powrotnej kanonil gnieźnieński odwiedzil jeszcze Faenzę, gdzie - jak zauważył - „Tu porcelana czyli fajans od wielu wieków wynaleziona. Ta na której jadłem w austerii, mało ustępuje saskiej" ${ }^{104}$.

W nocy 17 marca 1789 r. podróżnicy wypoczęli w Bolonii i od tej pory wracali już tą samą drogą, którą przemierzył Pstrolioński w drodze do Rzymu, czyli przez Ferrarę, Wenecję, Treviso, Ranchetto dotarli do przejścia granicznego między Włochami a Austrią w Pontebie. I lutaj spotkało ich niemiłe przyjęcie. Odclajmy głos samemu kanonikowi: „Aż dotąd, to jest do Ponteby weneckiej i przedtem od niej jadąc do samego Rzymu, nie miałem zatrudnienia ${ }^{105}$ żadnego, tylko trzeba było pokazać na komorze świadectwo na cedule, jako $z$ kraju zdrowego jadę. Nigdzie w całych aż do Rzymu Włoszech nie przetrząsano mego pojazdu, dopiero przebywszy most do Ponteby austriackiej, doznałem w tym przylkrości. Co tylko stanąłem w austerii, oficjalista, celnik austriacki, kufry każe otwierać, i roztrząsa rzeczy, i kazawszy od nich zapłacić sobie 'transito' oprócz tego jeszcze kazał sobie dać dukatów 6. ,A to za co? pytam się; ,pro vadimonio' odpowiada ten ździerca, ,zebyście na bok z państwa austriackiego nie zboczyli z oszukaniem skarbu cesarskiego. - A cóż to za racja! A gdzie my odbierzemy te pieniądze? - Odbierzecie je na ostatniej doganie tej prowincji ${ }^{106}$. Zaplaćcie bez dysputy, macie na to bilet, który oto wam daję'. Trzeba było posłusznym być niesprawiedliwości i zostawić 6 dukatów na przepadek, bo $z$ ostatniej dogany prowincji Karyntii odesłano nas do Wiednia, gdzie ganiono tylko niesprawiedliwość celnika pontebskiego, ale nam nie powrócono" ${ }^{\text {"107. }}$. 
Nie lepsze doświadczenia spotkały księży Pstrokońskiego i Dembińskiego w Wiedniu: „Dnia 5 kwietnia przybyłem na południe do Wiednia, ale mię wprzód zaprowadzono na komorę, gdzie niemało miałem biedy, zachodów, frasunku i kłopotu $z$ celnikami, lubo nic wcale $z$ kontrabandy przy sobie w powozie nie miałem" ${ }^{108}$. Nic też dziwnego, że po takich przeżyciach zanotowal kanonik gnieźnieński następującą refleksję: „Stawiłem tu sobie w oczach Włochów, komparowałem ich z Austriakami; ci zdawali mi się względem tamtych, jak pycha względem pokory, jak barbarzyństwo względem grzeczności, jak złość względem dobroci; podobno tym nie ustępują sami Turcy w sprawiedliwości, ani nawet dzicy Amerykanie w grubiaństwie"109.

Po tych niemiłych przeżyciach, przez Opawę dotarł Pstrokoński do Wrocławia, gdzie rozstał się $z \mathrm{ks}$. Dembińskim, udając się do Lubinia, do swojego protektora, opata lubińskiego Michała Lipskiego. Tam - napisał Pstrokoński „porachowałem się $z$ workiem moim i wyrachowałem ekspensy w tej rzymskiej drodze mojej 400 dukatów. Zdawać się będzie komu, że wiele ekspensowałem, ale powiadam, że niewiele. Wiek mój, w którym już byłem natenczas, bo miałem lat 55, charakter kanonika gnieźnieńskiego i eks-prezydenta trybunału koronnego, potrzebowal inszej figury nad innych Polaków, a szczególniej w Rzymie. Niech ten przywiększy wydatek innych nie odraża od wojażowania do Rzymu, do tego miasta świętego, byle to czynił, nie dla samej ciekawości, ale dla cnoty, dla nauki, a przez cale zupelne trzy lata, nie utraci przy ochronie tyle, ile ja przez rok jeden wyszafowałem"110.

Na tym właściwie kończą się wspomnienia Pstrokońskiego dotyczące podróży do Rzymu, w dalszej części wspomnień mamy jeszcze rozdziały o konfederacji barskiej, kasacie jezuitów, prymasach Podoskim i Ostrowskim. Biorąc pod uwagę sposób opisu rzeczywistości, zwracanie uwagi na pewne fakty, pomijanie innych, są one bardzo podobne do tych scharakteryzowanych i cytowanych wyżej.

\section{Zakończenie}

Pamiętniki Baltazara Pstrokońskiego są przykładem wczesnej autobiografii przygotowanej w kręgu osób duchownych. Cechuje je używanie języka charakterystycznego dla duchowieństwa, wynikającego $z$ odpowiedniego systemu kształcenia i oddziaływania środowiska. Znajdujemy też w nich opisy - głównie refleksje dotyczące zabytków oglądanych w czasie podróży do Włoch i w Rzymie - które, w myśl teorii Bernsteina, można byłoby określić, jako posługiwanie się przez Pstrokońskiego kodem rozbudowanym. Charakter wspomnień kanonika gnieźnieńskiego jest wynikiem jego osobowości, ale też skutkiem oddziaływania zbiorowości kulturowej, bowiem, zgodnie $z$ teorią Edwarda Sapira: „Właściwym polem kultury jest interakcja poszczególnych jednostek oraz ujmując rzecz subiektywnie, świat znaczeń, które każda $z$ tych jednostek konstruuje sobie nieświadomie na podstawie swego udziału w tej interalkcji"111. 


\section{Przypisy:}

${ }^{1}$ M. Dernałowicz, Wstęp, w: Kufer Kasyldy czyli Wspomnienia z lat dziewczęcych, Wybór D. Stępniewska i B. Walczyna, Warszawa 1974, s. 6-7.

${ }^{2}$ A. Cieński, Pamiętnikarstwo polskie XVIII wieku, Wroclaw 1981, s. 203-204.

${ }^{3}$ Zob. np.: A. Giza, Zycie jako opowieśc. Analiza materiałów autobiograficznych w perspektywie socjologii wiedzy, Wroclaw 1991.

${ }^{4}$ Ibidem, s. 8.

${ }^{5}$ B. Bernstein, Socjolongwistyka a spoleczne problemy ksztalcenia, w: Jezyk i spoleczeństwo. Wybral i wstępem opatrzyl, M. Głowiński, Warszawa 1980, s. 92-100.

${ }^{6}$ Ibidem, s. 101.

${ }^{7}$ Ibidem, s. 102.

${ }^{8}$ Ibidem, s. 115.

${ }^{9}$ A. Giza, op. cit., s. 110.

${ }^{10}$ M. Aleksandrowicz, Pstrokoński Baltazar (Balcer), w: Polski słownik biograticzny, t. XXIX/2, z. 121, Kraków 1986 s. 263.

${ }^{11}$ Ibidem.

${ }^{12}$ Ibidem.

${ }^{13}$ Ibidem.

${ }^{14}$ Ibidem, s. 264.

${ }^{15} \mathrm{Z}$. Swiechowski, Baltazar Pstrokoński i jego stosunek do architektury, „Muzeum i Twórca" 1969, s. 485-492.

${ }^{16} \mathrm{M}$. Aleksandrowicz, op. cit., s. 264.

${ }^{17}$ Ibidem.

${ }^{18}$ Ibidem.

${ }^{19}$ Pamiętniki księdza Pstrokonskiego, kanonika katedralnego gnieźnieńskiego z rękopisnu wydane przez Edwarda Raczyńskiego. Wrocław: Nakładem Zygmunta Schlettera, 1844, „Obraz Polaków i Polski w XVIII wieku”.

${ }^{20}$ Rozdzial I. Pierwsze początki $i$ wychowanie (s. 1-11); R. II. Powołanie do stanu duchownego (s. 11-18); R. III. Promocja autora na kanonika (s. 18-36); R. IV. Dalsza promocja (s. 36-38); R. V. Urzędowanie w Trybunale Koronnym (s. 38-49); R. VI. O prymasie Eubieńskim (s. 49-56); R. VII. O kanclerzu Mlodziejowskim (s. 56-69); R. VIII. Podróż do Wloch (s. 69-88); R. IX. Pobyt w Rzymie (s. 88-112); R. X. Powrót do kraju (s. 113146); R. XI. Konfederacja barska (s. 147-153); R. XII. Skasowanie zakonu jezuitów (s. 154-162); R. XIII. Dalsze autora przygody (s. 162-163); R. XIV. O prymasie Podoskim (s. 164-169); R. XV. O prymasie Ostrowskim (s. 169-181).

${ }^{21}$ Pamiętniki księdza..., s. 181.

${ }^{22}$ Ibidem, s. 1.

${ }^{23}$ M. Aleksandrowicz, op. cit., s. 264.

${ }^{24}$ Pamiętniki księdza..., s. 3.

${ }^{25}$ Ibidem, s. 8.

${ }^{26}$ Ibidem, s. 11

${ }^{27}$ Ibidem, s. 10-11.

${ }^{28}$ Ibidem, s. 11.

${ }^{29}$ Ibidem, s. 12.

${ }^{30}$ Ibidem, s. 13.

${ }^{31}$ Ibidem, s. 15. 
${ }^{32}$ Ibidem, s. 30.

${ }^{33}$ Ibidem, s. 1.

${ }^{34}$ Ibidem, s. 3.

${ }^{35}$ Ibidem, s. 23.

${ }^{36}$ Józef, syn zmarlego brata Jędrzeja.

${ }^{37}$ Pamietniki księdza..., s. 35.

${ }^{38}$ Ibidem, s. 25.

${ }^{39}$ Ibidem, s. 20.

${ }^{40}$ Ibidem, s. 26.

${ }^{41}$ Ibidem, s. 27, chodzi o godności przy kolegiacie chockiej.

${ }^{42}$ Nieprzytomnemu - czyli niczego nie spodziewającemu się.

${ }^{43}$ Pamiętuiki księdza..., s. 38.

${ }^{44}$ Chodzi o śmierć kanonika kaliskiego, księdza Skoraszewskiego, którego Baltazar Pstrokonski byl koadiutorem.

${ }^{45}$ Pamietuiki księdza..., s. 31.

${ }^{46}$ Ibidem, s. 33.

${ }^{47}$ Ibidem, s. 47-48.

${ }^{48}$ W. Müller; W. Szczygielski, Mlodziejowski (Młodziejewski) Andrzej Mikołaj,

w: Polski słownik biograficzny, t. XXI, Wroclaw 1976, s. 428-432.

${ }^{49}$ Ibidem, s. 64.

${ }^{50}$ Andrzej Mlodziejowski zmarł w 1780 r.

${ }^{51}$ Panniętriki księdza..., s. 66, 67.

52 Ibidem, s. 67-68.

${ }^{53}$ M. Aleksandrowicz, op. cit., s. 263.

${ }^{54}$ Panietniki ksiedza..., s. 69-70.

${ }^{55}$ Ibidem, s. 70-71.

${ }^{56}$ Ibidem, s. $72,73,74$.

${ }^{57}$ Ibidem, s. 81.

${ }^{58}$ Ibidem, s. $81-82$.

${ }^{59}$ Ibidem, s. 83.

${ }^{60}$ Ibidem.

${ }^{61}$ Ibidem.

${ }^{62}$ Ibidem, s. 85.

${ }^{63}$ Santa Maria del Fiore.

${ }^{64}$ Panniętniki ksiegdza..., s. 86.

${ }^{65}$ Palazzo Vecchio (della Signoria) z XIII-XIV w.

${ }^{66}$ Pamiętniki ksiedza..., s. 86-87.

${ }^{67}$ Ibidem, s. 88.

${ }^{68}$ Ibidem, s. 89.

${ }^{69}$ Campagna, wl. - wieś.

${ }^{70}$ Villegiatura, wł. - letnisko.

${ }^{71}$ Pamiętniki ksiedza..., s. 90-92.

${ }^{72}$ Ibidem, s. 92.

${ }^{73}$ Ibidem.

${ }^{74}$ Ibidem, s. 94.

${ }^{75}$ Oczywiście chodzi o frutti di mare.

${ }^{76}$ Pamietniki księdza..., s. 95. 
${ }^{77}$ Ibidem.

${ }^{78}$ Około 1,5 litra.

${ }^{79}$ Pamiętniki księdza..., s. 96.

${ }^{80}$ Ibidem, s. 97.

${ }^{81}$ Ibidem, s. 98.

${ }^{82}$ Ibidem, s. 101-102.

${ }^{83}$ Ibidem, s. 105-106.

${ }^{84} \mathrm{~W}$ wydaniu Raczyńskiego jest ponylka, ponieważ nazwę placu zanotowano jako: Riazza Nazona.

${ }^{85}$ Pamiętniki księdza..., s. 93-94.

${ }^{86}$ Ibidem, s. 100.

${ }^{87}$ Ibidem, s. 104-105.

${ }^{88}$ Czyli 1767.

${ }^{89}$ Panniętniki księdza..., s. 99-100.

${ }^{90}$ Ibidem, s. 101.

${ }^{91}$ Ibidem, s. 102.

92 Amor, lac. ukochanie, miłość.

${ }^{93}$ Mora, lac. zatrzymanie, odkładanie.

${ }^{94}$ Pamiętniki ksiedza..., s. 113.

${ }^{95}$ M. Aleksandrowicz, op. cit., s. 263.

${ }^{97}$ Klemens XIII, Carlo dellla Torre Rezzonico, ur. 1693 zm. na pocz. 1769 r., kiedy Pstrokoński opuszczał już Rzym. Był on nieugiętym obrońcą zakonu jezuitów, czego dowodem są równiez Pamiętniki kanonika gnieźnieńskiego, w których znajdujemy m. in. takie zdanie: „General jezuicki z taką powolnością, jak ów Abraham jedynaka swego, 20000 synów swoich na przebłaganie majestatów ziemskich chciał ofiarować. Namiestnik Chrystusów, jako Bóg niegdyś samą chęcią Abrahama się kontentowal, wolal się sam wprzód pogrzebać (jakoż to mu śmierć przyblizylo), nizeli za życia swego patrzyć na tyle mogił zamęczonej niewinności, i na tyle tysięcy pogrzebanych ceremonii takich egzekwi z przedwiecznych wyroków, zostawił następcy swemu". (Pamietniki księdza..., s. 115.)

${ }^{97}$ Pamiętniki księdza..., s. 116.

${ }^{98}$ Ibidem, s. 120.

${ }^{99}$ Ibidem, s. 119.

${ }^{100}$ Ibidem, s. 122.

${ }^{101}$ Ibidem, s. 123-124.

${ }^{102}$ Bez podniebienia, czyli bez sklepienia, oczywiście chodzi tu o słynne Tempio Malatestiano, kościól S. Francesca przebudowany w XV wieku przez L. B. Alber tiego na zlecenie Sigismondo Malatesta (pol. XV w.) na mauzoleum rodu Malatestów, z bogatym wystrojem rzeźbiarskin i freskami Pierro della Francesca.

${ }^{103}$ Pamietuiki ksiedza..., s. 125.

${ }^{104}$ Ibidem, s. 126.

${ }^{105} \mathrm{Czyli}$ - utrudnień.

${ }^{106}$ Czyli - Karyntii.

${ }_{107}$ Pamiętriki ksiedza..., s. 137-138.

${ }^{108}$ Ibidem, s. 139.

${ }^{109}$ Ibidem.

${ }^{110}$ Ibidem, s. 141.

${ }^{111}$ E. Sapir, Kultura, jezyk, osobowośc: wybrane eseje, Warszawa 1978, s. 65. 